\title{
El modelo organizativo de la Oficina de Gestión Judicial Poder Judicial de la Provincia de Santa Fe
}

The Organizational Model of the Judicial Management

Office in the Judicial Power of Santa Fe Province

O modelo organizacional do Gabinete de Gestão Judiciária

Poder Judiciário da Província de Santa Fe

\section{Mariana Jimena Drago}

Universidad Nacional del Litoral, Argentina

E-mail:marianadrago@gigared.com

Fecha de recepción: 14/09/2018 Fecha de aceptación: 06/06/2019

Palabras clave

- Modelo organizativo

- Estructura administrativa

- Gestión de personal

- Cultura organizativa

- Cambio organizativo

\section{Resumen}

Las políticas de diseño administrativo y de reorganización incluyen deliberaciones en torno a formas organizacionales, pero también implican luchas en torno a símbolos, legitimidad e identidad de la administración pública. Una teoría sobre la administración pública debe dar cuenta de la complejidad de la organización administrativa, de sus actores y del cambio que en ella opera.

En el presente trabajo se efectuará un estudio organizativo aplicado a la Oficina de Gestión Judicial perteneciente al Poder Judicial de la Provincia de Santa Fe y se realizará una propuesta organizativa global.

Se considerarán los ámbitos conceptuales fundamentales que agrupa cualquier organización pública: ámbito sociotécnico, ámbito políticocultura y ámbito de control y mejora.

Por último, se aplicará la técnica de los Modelos de Orientación Estratégica (MOEs) a la Oficina de Gestión Judicial mostrando diferentes escenarios potenciales de cambio.

\footnotetext{
Abstract

Administrative design and reorganization policies include deliberations on organizational forms. Furthermore, these policies involve struggles related to the symbols, legitimacy and identity of the public administration. A
} 
Keywords

- Organizational model

- Administrative structure

- Personnel management

- Organizational culture

- Organizational change

Palavras-chave

- Modelo organizacional

- Estrutura administrativa

- Gestão de pessoal

- Cultura Organizacional

- Mudança organizacional public administration theory must account for the complexity of the administrative organization, its actors and the change that takes place in it.

The purpose of the present work is to conduct an organizational study applied to the Office of Judicial Management belonging to the Judicial Power of Santa Fe Province. Moreover, a global organizational proposal will be made.

The fundamental conceptual areas of any public organization will be considered: socio-technical field, political-cultural field and control and improvement field.

Finally, the technique of Strategic Orientation Models (SOMs) will be applied to the Judicial Management Office, displaying different potential scenarios of change.

\section{Resumo}

As políticas de desenho administrativo e de reorganização incluem deliberações em torno de formas organizacionais, mas também envolvem lutas em torno de símbolos, legitimidade e identidade da administração pública. Uma teoria sobre a administração pública deve dar conta da complexidade da organização administrativa, de seus atores e da mudança que opera nela.

No presente trabalho será realizado um estudo organizacional aplicado ao Gabinete de Gestão Judiciária pertencente ao Poder Judiciário da Província de Santa Fé e será feita uma proposta organizacional global.

Serão consideradas as áreas conceituais fundamentais que agrupa qualquer organização pública: área sociotécnica, área político-cultural e escopo de controle e aprimoramento.

Finalmente, será aplicada a técnica de Modelos de Orientação Estratégica (MOEs) ao Gabinete de Gestão Judiciária, apresentando diferentes cenários potenciais de mudança. 